\title{
Faktor- Faktor Yang Berhubungan Dengan Pemilihan Metode Kontrasepsi Jangka Panjang (MKJP) Pada Akseptor Kb Di Puskesmas Purwosarikota Surakarta
}

\author{
Ratnasari Hasibuan ${ }^{1}$, Izzatul Arifah ${ }^{2}$, Tanjung Anitasari Indah Kusumaningrum. ${ }^{3}$ \\ ${ }^{123}$ Program Studi Kesehatan Masyarakat Universitas Muhammadiyah Surakarta \\ Jl. A. Yani, Pabelan, Kartasura, Surakarta. \\ Email: ratnasarihsb@gmail.com ${ }^{1}$, izzatul.arifah@ ums.ac.id $^{2}$, \\ tanjung.anitasari@ums.ac.id ${ }^{3}$
}

Tanggal submisi: 2 Juni 2020; Tanggal penerimaan: 27 Februari 2021

\begin{abstract}
ABSTRAK
MKJP merupakan metode kontrasepsi cost efficien untuk mencegah kehamilan dan secara program efektif dalam menurunkan TFR serta menekan laju pertumbuhan penduduk. Tujuan penelitian adalah menganalisis hubungan jumlah anak yang diinginkan, dukungan suami, dan efek samping dengan pemilihan Metode Kontrasepsi Jangka Panjang (MKJP) pada Akseptor KB di Puskesmas Purwosari KotaSurakarta. Jenis penelitian ini adalah observasional dengan pendekatan cross sectional. Penelitian ini dilaksanakan pada bulan SeptemberOktober 2019. Populasi penelitan 1.502 PUS usia 17-49 tahun akseptor KB di wilayah kerja Puskesmas Purwosari. Jumlah sampel penelitian sebanyak 282 responden yang dipilih dengan menggunakan teknik proportionate random sampling. Pengambilan data dengan cara wawancara terstruktur menggunakan kuesioner yang valid dan reliabel. Hasil analisis data berdasarkan uji Chi Square menunjukkan bahwa ada hubungan antara jumlah anak yang diinginkan $(p=0,012)$, dukungan suami $(p=0,045)$, dan efek samping $(p=0,001)$ dengan pemilihan MKJP. Kesimpulannya adalah responden dengan jumlah anak yang diinginkan terpenuhi, mendapatkan dukungan suami, dan tidak mengalami efek samping cenderung memilih menggunakan MKJP.Disarankan bagi Bidan untuk memberikan Informed Choice kepada calon akseptor KB, sehingga dapat memilih kontrasepsi karena tahu kelebihan dan kekurangan dalam hal ini efek samping dari setiap metode kontrasepsi. Kemudian apabila ada efek samping yang dirasakan, PUS paham tentang cara mengatasinya.
\end{abstract}

Katakunci : Dukungan Suami, Efek Samping, Jumlah Anak yang Diinginkan, MKJP

\begin{abstract}
LTCM is a cost-efficient method of contraception to prevent pregnancy and is programmatically effective in reducing TFR and reducing the rate of population growth. The purpose of this study was to analyze the relationship between the
\end{abstract}


number of children wanted, husband's support, and side effects with the selection of the Long-Term Contraception Method (LTCM) at the family planning acceptor at Purwosari Public Health Center, Surakarta. This type of research is observational with cross sectional approach. This research was conducted in September-October 2019. The research population was 1,502 aged 17-49 years old family planning acceptors in the working area of Purwosari Public Health Center. The number of research samples were 282 respondents who were selected using proportionate random sampling techniques. Retrieval of data by structured interview using a valid and reliable questionnaire. The results of data analysis based on the Chi Square test showed that there was a relationship between the number of children wanted $(p=0.012)$, husband's support $(p=0.045)$, and side effects $(p=0.001)$ with the LTCM selection. The conclusion is that respondents with the desired number of children are met, have the support of their husbands, and do not experience side effects, they tend to choose using the LTCM. It is recommended for Midwives to give Informed Choice to prospective family planning acceptors, so they can choose contraception because they know the advantages and disadvantages in this case the side effects of each contraceptive method. Then if there are any side effects felt, childbearing age can understands how to overcome the side effects.

Keywords : Husband Support, LTCM, Number of Children Wanted, Side Effects

ISSN 1979-7621 (Print). ISSN 2620-7761 (Online).

DOI : $10.23917 / j k . v 14 i 1.9215$

\section{PENDAHULUAN}

MKJP telah memberikan kontribusi terhadap program KB yaitu peningkatan pemakaian kontrasepsi modern/Contraceptive Prevalence Rate $(C P R)$ dan menurunkan angka kelahiran total/Total Fertility Rate (TFR) Indonesia. Selain dari sisi program, MKJP juga memiliki keuntungan dari sisi pengguna. MKJP dapat dipakai dalam waktu lama serta lebih aman dan efektif dalam menjarangkan kehamilan (Prawiro, 2012).

Pada tahun 2017 akseptor KB aktifdi Indonesia sebagian besar didominasi oleh pengguna non MKJP yaitu suntik dan pil KB $(81,23 \%)$ (Kemenkes, 2018). Di Jawa Tengah mayoritas akseptor KB aktif menggunakan non MKJP (28,92\%). Sedangkan Kota Surakarta jika dilihat dari proporsi jenis kontrasepsi, peserta KB aktif MKJP lebih tinggi dibandingkan dengan Jawa Tengah $(29,6 \%)$ (Dinkes Surakarta, 2018). Puskesmas Purwosari merupakan salah satu puskesmas yang ada di Kota Surakarta yang memiliki cakupan KB baru paling rendah $(0,4 \%)$. Total penggunaan non MKJP mencapai $70,4 \%$ sedangkan penggunaan MKJP hanya 29,6\% dari sasaran target $21,7 \%$. Meskipun telah mencapai target, akan tetapi sebagian besar akseptor KB aktif yang ada di Puskesmas Purwosari mengguanakan suntik KB (29\%) (Puskesmas Purwosari, 2018). Berdasarkan data diatas, dapat disimpulkan bahwa MKJP bukanlah pilihan mayoritas pasangan usia subur akseptor KB di Puskesmas Purwosari.

Faktor-faktor yang dapat mempengaruhi akseptor KB dalam memilih metode kontrasepsi antara lain faktor ibu (faktor non kesehatan yaitu gaya hidup, jumlah anak yang diinginkan, dan pengalaman 
kontrasepsi yang lalu, faktor kesehatan yaitu umur, frekuensi senggama, status kesehatan, riwayat haid, riwayat keluarga, riwayat pemeriksaan fisik dan panggul), faktor pasangan (dukungan suami), dan faktor metode kontrasepsi (efektivitas, efek samping, dan biaya) (Proverawati dkk, 2010).

Friedman, et al (1994) mengemukakan bahwa jumlah anak yang diinginkan adalah salah satu factoryang mempengaruhi dalam menggunakan kontrasepsi. Berdasarkan penelitian Hartoyo dkk (2011), menunjukkan nilaiR ${ }^{2}$ sebesar 0,24 artinya jumlah anak yang diinginkan berpengaruh pada keikutsertaan dalam KB sebesar 24\%. Selain itu, faktor pasangan yaitu dukungan suami dapat mempengaruhi akseptor dalam pemilihan kontrasepsi (Proverawati dkk, 2010). Suami memiliki pengaruh terhadap pilihan alat kontrasepsi $\mathrm{KB}$ yang akan dipakai istri. Akan tetapi, hasil penelitian Alfiah (2015) menunjukkan variabel dukungan suami $(p=1)$, sehingga dapat disimpulkan bahwa tidak ada hubungan yang signifikan antara dukungan suami dengan penggunaan MKJP.Faktor yang perlu dipertimbangkan dalam memilih alat kontrasepsi salah satunya yaitu adanya efek samping yang potensial terjadi (BKKBN, 2011). Penelitian yang dilakukan Triana,dkk (2011) menunjukkan alasan wanita tidak memakai KB 26\% karena takut efek samping KB.

Setelah melakukan wawancara dengan PUS di Puskesmas Purwosari didapatkan sebagian besar menggunakan suntik KB dikarenakan masih muda, ingin memiliki anak lagi dalam waktu dekat, takut dengan prosedur pemasangan IUD ataupun implan, dan larangan suami menggunakan MKJP dikarenakan alasan sakit saat berhubungan seksual. Sedangkan bagi akseptor KB MKJP menggunakan IUD atau implan dikarenakan alasan tidak mempengaruhi berat badan, nyaman, merasa sudah cocok dan terbukti dapat menunda kehamilan sesuai dengan keinginan. Kemudian alasan responden yang menggunakan MOW yaitu karena usia yang sudah tua, anak sudah banyak, dan rekomendasi oleh petugas kesehatan.Maka dapat disimpulkan masih banyak PUS yang menggunakan KB berdasarkan jumlah anak, arahan dari suami, dan efek samping KB yang dirasakan.

Berdasarkan penelitian Finealia (2011), menyatakan bahwa diperlukannya upaya meneliti lebih lanjut dan mendalam terhadap faktorfaktor lain yang mungkin berhubungan dengan penggunaan MKJP dan penelitian ini juga mendorong lebih dilakukan penelitian untuk mengetahui faktor yang berhubungan dengan pemilihan MKJP pada PUS. Sehingga dari pembahasan diatas peneliti tertarik untuk meneliti mengenai jumlah anak yang diinginkan, dukungan suami, dan efek samping dengan pemilihan Metode Kontrasepsi Jangka Panjang (MKJP) pada akseptor KB di Puskesmas Purwosari Kota Surakarta.

\section{METODE PENELTIAN}

Jenis penelitian ini adalah observasional dengan pendekatan cross sectional. Penelitian ini dilakukan pada bulan September-Oktober 2019. Tempat penelitian di tiga wilayah kerja Puskesmas Purwosari yaitu: Kelurahan Purwosari, Kerten, dan Jajar. Populasi dalam penelitian ini yaitu 1.502 PUS usia 17-49 tahun yang merupakan aksptor KB yang ada di Puskesmas Purwosari. Jumlah sampel pada penelitian ini sebanyak 282 responden. Sampel diambil menggunakan teknik proportionate random sampling. Sehinga didapatkan kelurahan Purwosari 93 responden, kelurahan Kerten 94 responden, dan kelurahan Jajar 95 responden. Penelitian 
inimenetapkan kriteria inklusi yaitu bersedia menjadi responden, bertempat tinggal di Kelurahan Purwosari, Kerten, dan Jajar, dan dapat ditemui saat penelitian maksimal 3 kali percobaan.Jenis data pada penelitian ini meliputi data kategorik yaitu: pemilihan MKJP, jumlah anak yang diinginkan, dukungan suami, dan efek samping. Sumber data pada penelitian ini menggunakan data primer dan data pendukung. Instrumen penelitian yang digunakan yaitu kuesioner dan teknik pengambilan data dengan cara wawancara door to door ke rumah reponden. Analisis data penelitian ini adalah analisis univariat untuk menggambarkan karakteristik responden penelitian dalam bentuk disribusi frekuensi dan persentase. Analisis bivariat untuk mengetahui hubungan antara jumlah anak yang diinginkan, dukungan suami, dan efek samping dengan pemilihan MKJP dengan menggunakan uji statistik ChiSquare.

\section{HASIL DAN PEMBAHASAN}

Berdasarkan karakteristik usia, rata-rata usia responden adalah $35,68 \pm 6,95$ tahun, sebagian besar berusia $>35$ tahun sebanyak 149 orang $(53 \%)$. Usia responden termuda yaitu 17 tahun dan tertua berusia 49 tahun. Berdasarkan karakteristik pendidikan terakhir diketahui mayoritas respondentamatan SMA $(47,5 \%)$ dan pekerjaan sebagai Ibu Rumah Tangga $(79,1 \%)$. Distribusi frekuensi karakteristik responden dapat dilihat pada Tabel 1.

Tabel 1. Distribusi Frekuensi Karakteristik Responden

\begin{tabular}{llrr}
\hline Karakteristik & Kategori & $\mathbf{n}$ & $\mathbf{\%}$ \\
\hline Usia Istri & $<20$ & 5 & 2 \\
& $20-35$ & 128 & 45 \\
& $>35$ & 149 & 53 \\
& Rerata \pm SD & $35,68 \pm$ & 6,95 \\
& Median (min:maks) & 36,50 & $(17: 49)$ \\
\hline Pendidikan terakhir Istri & Tamat SD & 30 & 11 \\
& Tamat SMP & 59 & 21 \\
& Tamat SMA & 134 & 48 \\
& Tamat Perguruan Tinggi & 59 & 21 \\
\hline Pekerjaan Istri & IRT & 223 & 79 \\
& Swasta & 31 & 11 \\
& PNS & 3 & 1 \\
& Dagang/wiraswasta & 25 & 9 \\
\hline Jumlah & & $\mathbf{2 8 2}$ & $\mathbf{1 0 0}$ \\
\hline
\end{tabular}

Pada Tabel 2. menunjukkan bahwa mayoritas responden menggunaan kontrasepsi yaitu non MKJP 207 orang $(73,4 \%)$. Mayoritas responden mengalamiefek samping dari penggunaan kontrasepsi sebanyak 156 orang (55\%). Distribusi frekuensi jumlah anak yang dimiliki oleh responden mayoritas telah memiliki 2 anak sebanyak 125 orang (44\%)dan yang paling sedikit dengan 1 orang anak sebanyak 118 orang (42\%). Harapan jumlah anak mayoritas responden ingin memiliki 2 orang anak sebanyak 191 (68\%) dan yang paling sedikit dengan harapan jumlah anak 1 anak sebanyak 19 
orang (7\%). Pada keinginan menambah menjawab "Tidak" sebanyak 223 orang anak kembali waktu 2 tahun, mayoritas (79\%).

Tabel 2. Distribusi Frekuensi Berdasarkan Penggunaan Kontrasepsi dan Preferensi Fertilitas

\begin{tabular}{llrr}
\hline Karakteristik & Kategori & n & \% \\
\hline Jenis Kontrasepsi & MKJP & 75 & 27 \\
& Non MKJP & 207 & 73 \\
\hline Efek samping & Ya & 156 & 55 \\
& Tidak & 126 & 45 \\
\hline Jumlah anak yang dimiliki & 1 & 118 & 42 \\
& 2 & 125 & 44 \\
& $\geq 3$ & 39 & 14 \\
\hline Harapan jumlah anak & 1 & 19 & 7 \\
& 2 & 191 & 68 \\
& $\geq 3$ & 72 & 25 \\
\hline Ingin anak lagi dalam 2 tahun & Ya & 59 & 21 \\
& Tidak & 223 & 79 \\
\hline Jumlah & & $\mathbf{2 8 2}$ & $\mathbf{1 0 0}$ \\
\hline
\end{tabular}

Tabel 3.Distribusi Frekuensi Berdasarkan Hubungan Antara Jumlah Anak Yang Diinginkan, Dukungan Suami, Dan Efek Samping Dengan Pemilihan MKJP

\begin{tabular}{|c|c|c|c|c|c|c|c|c|}
\hline \multirow{3}{*}{ Variabel } & \multicolumn{4}{|c|}{ Pemilihan MKJP } & \multirow{2}{*}{\multicolumn{2}{|c|}{ Total }} & \multirow{3}{*}{ P value } & \multirow{3}{*}{$C C$} \\
\hline & \multicolumn{2}{|c|}{ MKJP } & \multicolumn{2}{|c|}{ Non MKJP } & & & & \\
\hline & $\mathbf{n}$ & $\%$ & $\mathbf{n}$ & $\%$ & $\mathbf{n}$ & $\%$ & & \\
\hline \multicolumn{9}{|c|}{ Jumlah anak yang diinginkan } \\
\hline Terpenuhi & 42 & 34,1 & 81 & 65,9 & 123 & 100 & \multirow{2}{*}{0,012} & \multirow{2}{*}{0,149} \\
\hline Tidak Terpenuhi & 33 & 20,8 & 126 & 79,2 & 159 & 100 & & \\
\hline \multicolumn{9}{|l|}{ Dukungan Suami } \\
\hline Mendukung & 42 & 32,3 & 88 & 67,7 & 130 & 100 & \multirow{2}{*}{0,045} & \multirow{2}{*}{0,119} \\
\hline Kurang Mendukung & 33 & 21,7 & 119 & 78,3 & 152 & 100 & & \\
\hline \multicolumn{9}{|l|}{ Efek Samping } \\
\hline Ada efek samping & 29 & 18,6 & 127 & 81,4 & 156 & 100 & \multirow{2}{*}{0,001} & \multirow{2}{*}{0,198} \\
\hline Tidak ada efek samping & 46 & 36,5 & 80 & 63,5 & 126 & 100 & & \\
\hline
\end{tabular}

Berdasarkan Tabel 3, didapatkan hasil uji chi-square dengan nilai p-value 0,012>0,05 sehingga dapat disimpulkan bahwa ada hubungan antara jumlah anak yang diinginkan dengan pemilihan MKJP pada akseptor KB di Puskesmas Purwosari Kota Surakarta. Hasil penelitian ini sejalan dengan hasil penelitian yang dilakukan oleh Paskaria (2015)dengan nilaip $p=0,0078$ yang menunjukkan ada hubungan yang bemakna antara jumlah anak yang diinginkan dengan pemilihan MKJP.
Hasil penelitian ini menunjukkan bahwa responden yang menggunakan MKJP cenderung memiliki jumlah anak yang diinginkan telah terpenuhi yaitu sejumlah 42 responden (34,1\%). Sedangkan responden yang menggunakan non MKJP cenderung memiliki jumlah anak yang diinginkan tidak terpenuhi yaitu sejumlah 126 orang (79,2\%). Hasil penelitian ini sejalan dengan penelitian yang dilakukan oleh Fienalia (2011) dengan nilai $p=0,000$ yang menunjukan ada hubungan antara jumlah anak hidup 
dengan penggunaan Metode Kontrasepsi Jangka Panjang di Puskesmas Pancoran Mas.

Hasil penelitian menunjukkan bahwa responden MKJP mayoritas memiliki 2 orang anak dan mayoritas jumlah anak harapan yaitu 2 anak. Sehingga dapat disimpulkan bahwa jumlah anak yang dimiliki saat ini telah sesuai dengan harapan responden. Ini sejalan dengan penelitian yang dilakukan Singh et al. (2010), bahwa banyak keluarga akan terus memiliki anak sampai mencapai ukuran keluarga yang diinginkan. Berdasarkan penelitian mayoritas responden yang berusia $>35$ tahun $(52,8 \%)$ dan tidak menginginkan anak kembali dalam waktu 2 tahun (91,3\%). Hal ini sejalan dengan penelitian yang dilakukan oleh Anggraeni (2014), dimana ada hubungan antara usia >30 tahun dengan menggunakan MKJP. Keluarga yang memiliki anak satu keluarga tersebut untuk menambah anggota keluarga.Keinginan mempunyai anak lagi memengaruhi penggunaan KB yang dipakai. Penelitian ini didukung oleh Maryatun (2007), yang menyatakan bahwa keinginan memiliki anak disesuaikan dengan jumlah anak yang ideal yang sebelumnya sudah ditentukan.

Sehingga bagi pengelola program $\mathrm{KB}$ perlu melakukan upaya yang intensif dalam menetapkan pemetaan segmentasi sasaran program KB khususnya MKJP. Dimana akseptor KB MKJP memiliki karakteristik seperti telah memiliki jumlah anak yang diinginkan terpenuhi dan berumur $>35$ tahun. Maka bagi PUS yang telah berumur $>35$ tahun dan telah memiliki anak sesuai dengan harapan dapat diarahkan oleh Bidan/PLKB untuk menggunakan Metode Kontrasepsi Jangka Panjang (MKJP) dalam membatasi kelahiran anak karena memiliki efektivitas tinggi dan dapat digunkan hingga 5-10 tahun.

Berdasarkan Tabel 3, didapatkan hasil uji chi-squaredengan nilai p-value 0,045> 0,05 sehingga dapat disimpulkan bahwa ada hubungan antara dukungan suami dengan pemilihan MKJP pada akseptor KB di Puskesmas PurwosariKota Surakarta. Hasil penelitian ini sejalan dengan penelitian yang dilakukan oleh Wulandari (2015), bahwa dukungan suami berpengaruh terhadap pemilihan alat kontrasepsi pada PUS di Puskesmas Ngoresan, Kota Surakarta.

Hasil penelitian ini menunjukkan bahwa responden yang menggunakan MKJP cenderung mendapat dukungan suamiyang baik yaitu sejumlah 42 responden $(32,3 \%)$, sedangkan responden yang menggunakan non MKJP cenderungkurang mendapatdukungan suami yaitu sejumlah 119 responden $(78,3 \%)$. Pada penelitian ini didapatkan mayoritas responden MKJP mendapat dukungan sebesar 32,3\%. Hasil rekapitulasi kuesioner didapatkan rata-rata responden MKJP mendapat dukungan informatif sebesar $76 \%$. Hasil penelitian ini sesuai dengan penelitian Arini (2015), dimana sebagian besar ibu mendapat dukungan informasional penggunaan MKJP baik (74,4\%).Dukungan informatif yang diberikan suami untuk istri saat berKB yaitu suami memberitahu Ibu tentang macam-macam KB MKJP. Akan tetapi dalam penelitian ini hanya sedikit suami yang mencari informasi tentang MKJP dari media cetak ataupun internet. Berdasarkan hasil penelitian,rata-rata responden MKJP mendapat dukungan penilaian sebesar $81 \%$. Hasil penelitian ini sesuai dengan penelitian Arini (2015), dimana sebagian besar ibu mendapat dukungan penilaian penggunaan MKJP baik $(76,4 \%)$.Dukungan penilaian suami untuk istrinya mayoritasberupa suami ikut menentukan jenis kontrasepsi yang Ibu gunakan. Akan tetapi hanya sedikit suami yang menyarankan istri untuk ganti kontrasepsi saat mengalami keluhan/ketidaknyamanan berKB.

Pada aspek dukungan instrumental, rata-rata responden MKJP mendapat dukungan sebesar $85 \%$. Hasil penelitian ini sesuai dengan penelitian Putri (2017), dimana sebagian besar ibu mendapat 
dukungan instrumental penggunaan MKJP baik $(76,4 \%)$. Dukungan instrumental yang diberikan suami kepada istri mayoritasberupa suami menyediakan dana untuk menggunakan KB. Namun terdapat dukungan dari suami yang sebagian besar kurang yaitu menemanike Dokter/Bidan saat kunjungan ulang KB. Berdasarkan hasil penelitian didapatkan rata-rata responden MKJP mendapat dukungan emosional sebesar $89,3 \%$. Hal ini berbeda dengan penelitian oleh Putri (2017), dimana sebagian besar ibu mendapat dukungan emosionalpenggunaan MKJP kurang (55\%). Dukungan emosional yang diberikan suami untuk istriberupa mendengarkan keluhanibu saat terjadi efek sampingKB dan membantu mengurus rumah ketika ibu sakit efek menggunaan KB. Namun terdapat dukungan emoional dari suami yang sebagian besar kurang yaitu suami marah apa bila menstruasi ibu menjadi lebih lama.

Berdasarkan hasil jawaban responden, dukungan suami yang paling rendah yaitu berupa menyarankan ibu untuk ganti kontrasepsi saatmengalami keluhan/ketidaknyamanan berKB $(31,9 \%)$ dan menemani ke dokter/bidan saat kunjungan ulang $\mathrm{KB}(24,1 \%)$, dan suami marah apabila menstruasi ibu menjadi lebih lama $(56,7 \%)$. Hal ini sejalan dengan penelitian Putri (2017), dimana sebagian besarsuami tidak meluangkan waktunya untuk mengantar atau mendampingi istri ketika istri ingin kembali kontrol IUD atau implant dan suami tidak memperhatikan kondisi kesehatan istri walaupun istri tidak menggunakan alat kontrasepsi IUD atau implant.

Berdasarkan pembahasan diatas dapat disimpulkan bahwa dukungan yang paling banyak diberikan suami dalam penggunaan MKJP yaitu dukungan emosional. Sedangkan dukungan yang paling rendah diberikan yakni dukungan informasional. Sehingga diharapkan bagi Bidan dan PLKB dapat meningkatkan promosi dan penyuluhan kepada suami akseptor KB untuk meningkatkan pengetahuan, informasi, dan dukungan suami untuk akseptor $\mathrm{KB}$ mengenai kesehatan reproduksi dan MKJP.

Berdasarkan Tabel 3, didapatkan hasil uji chi-square dengan nilai $p$-value 0,001>0,05 sehingga dapat disimpulkan bahwa ada hubungan antara efek samping dengan pemilihan MKJP pada akseptor KB di Puskesmas PurwosariKota Surakarta. Hasil penelitian inisejalandengan hasil penelitian Sumartini dan Indriani (2014), menunjukkan ada hubungan antara efek samping denngan penggunaan MKJP. Hasil penelitian ini menunjukkan bahwa responden yang menggunakan MKJP cenderung tidak mengalami efek samping yaitu sejumlah 46 responden (36,5\%), sedangkan responden yang menggunakan non MKJP cenderung mengalami efek samping yaitu sejumlah 127 responden $(81,4 \%)$.Hal ini dapat disebabkan karena akseptor MKJP sebenarnya merasakan efek samping saat penggunaan KB MKJP akan tetapi berpersepsi bahwa tidak mengalami efek samping. Hasil penelitian Hutaminingsih (2013), menunjukkan ketika mengalami efek samping ada dua persepsi. Persepsi yang petama yaitu alat kontrasepi menjadipembebas perempuan dari efek samping yang ditimbulkan alat kontrasepi sebelumnya.Persepsi yang ke kedua perempuan tidak apa-apa dengan efek samping yang dirasakannya.

Berdasarkan riwayat penggunaan $\mathrm{KB}$ yang lalu, mayoritas pengguna MKJP sebelumnya menggunakan kontrasepi non MKJP (58,7\%). Kemudian alasan berhenti menggunakan $\mathrm{KB}$ yang lalu mayoritas dikarenakan mengalami efek samping $(87,7 \%)$. Berdasarkan hasil jawaban responden mayoritas efek samping sekarang yang dialami akseptor MKJP sama seperti saat menggunakan non MKJP yaitu haid tidak teratur dan darah haid yang menjadi lebih banyak. Efek samping yang paling banyak mereka alami yaitu haid lebih lama dan darah haid yang lebih banyak. Hasil penelitian ini sejalan dengan penelitian yang dilakukan oleh Amran (2013), diman PUS yang merasakan efek 
samping pada kontrasepsi sebelumnya memiliki peluang lebih sebesar4,27 kali (95\% CI: 3,21-5,66) untuk berpindah dari non MKJP keMKJP.

Meskipun memiliki efek samping yang sama, responden MKJP tetap memilih menggunakan IUD atau implan dikarenakan memiliki efektivitas tinggi, dapat digunakan dalam waktu 5-10 tahun, dan sangat praktis karena tidak perlu mengingat-ingat waktu kontrol ulang. Hal ini sejalan dengan penelitian Purnandias dan Dharminto (2016), menunjukkan bahwa ada hubungan kepraktisan IUD dengan keikutsertaan akseptor IUD. Sehingga menunjukkan manfaat kepraktisan menggunakan MKJP dapat menutupi kekurangan dari penggunaan MKJP yaitu berupa efek samping yang ditimbulkan.

Akan tetapi, hasil dari penelitian mayoritas tindakan yang dilakukan responden saat mengalami efek samping KB saat ini adalah dibiarkan $(55,7 \%)$. Dari hasil wawancara didapatkan bahwa responden berpersepi bahwa efek samping yang sebenarnya dialami saat ini bukan merupakan keluhan. Sehingga responden tetap nyaman menggunkan kontrasepsi yang digunakannya saat ini serta tidak ingin berhenti atau ganti metode kontrasepsi. Maka disarankan bagi Bidan untuk memberikan Informed Choicekepada calon akseptor KB agar calon akseptor KB dapat mengenali kebutuhannya, memilih solusi terbaik, dan buat membuat keputusan yang paling sesuai dengan kondisi apabila mengalami efek samping dalam penggunaan $\mathrm{KB}$.

\section{KESIMPULAN}

Pada penelitian ini dari 282responden mayoritas menggunakan kontrasepsi non MKJP yaitu sebanyak 42 responden $(34,1 \%)$. Mayoritas responden mengalami efek samping yaitu sebanyak
156 orang $(55 \%)$. Sebagianbesar responden memilki 2 orang anak yaitu sebanyak 125 responden (45\%). Mayoritas responden memiliki harapan jumlah anak 2 orang yaitu sebanyak 191 responden (68\%). Sementara pada aspek menginginkan anak kembali dalam waktu 2 tahun, mayoritas responden menjawab "Tidak" yaitu sebanyak 223 orang (79\%).Variabel yang berhubungan dengan pemilihan MKJP adalah jumlah anak yang diinginkan (pvalue $=0,012), \quad$ dukungansuami $\quad(p$ value $=0,045)$, dan efek samping $(p$ value $=0,001)$.

Diperlukan upaya Bidan dan PLKB untuk meningkatkan target segmentasi pengguna MKJP. Seperti mengarahkan PUS yang telah berusia >35 tahun dan telah memiliki jumlah anak yang diinginkan terpenuhi untuk menggunakan MKJP. Dalam meningkatkan peserta KB aktif MKJP, Bidan dan PLKB perlu memberikan promosi kesehatan dan konseling tentang MKJP serta menekankan macam-macam efek samping dari KB. Promosi kesehatan dan konseling tidak hanya dilakukan pada istri saja tetapi juga melibatkan suami. Upaya meningkatkan pengetahuan juga dapat dilakukan oleh akseptor KB dengan mengajak suami saat konsultasi pemilihan KB.Bidan juga perlu memberikan Informed Choice kepada calon akseptor KB sehingga calon akseptor KB dapat mengenali kebutuhannya, memilih solusi terbaik, dan buat membuat keputusan yang paling sesuai dengan kondisi apabila mengalami efek samping dalam penggunaan $\mathrm{KB}$.

\section{UCAPAN TERIMA KASIH}

Ucapan terimakasih diberikan pada orang tua, dosen pembimbing, dan temanteman Prodi Kesehatan Masyarakat, FIK Universitas Muhammadiyah Surakarta yang telah mendukung penelitian ini.

\section{DAFTAR PUSTAKA}


Alfiah, Ismi Dzalfah. (2015). Faktor-faktor yang berhubungan dengan peggunaan Metode Kontrasepsi Jangka Panjang di Wilayah Kerja Puskesmas Kecamatan Kalideres Tahun 2015. Jakarta: UIN.

Amran, Yuli. (2013). Hubungan Antara Motivasi Keluarga Berencana dan Persepsi Terhadap Alat Kontrasepsi dengan Pola Penggantian Metode Kontrasepsi di

Nusa Tenggara Barat. Jakarta: Fakultas Kesehatan Masyarakat, Universitas Indonesia.

Anggraeni, Putri. (2014). Determinan Pengguaan Metode Kontrasepsi Jangka Panjang (MKJP) Pada Akseptor KB di Wilayah Kerja Puskesmas Pamulang Tahun 2014. Jakarta: UIN.

Arini, R.D. (2015). Hubungan Antara Dukungan Suami dan Pengetahuan Ibu dengan Pemilihan Alat Kontrasepsi Intra Uterine Device (IUD) di Puskesmas Polokarto Kabupaten Sukoharjo. Surakarta: UMS.

Badan Pusat Statistik. (2017). Badan Pusat Statistik Tabel Dinamis. Diambil kembali dari Badan Pusat Statistik: https://www.bps.go.id/site/resultTab

BKKBN. (2011). Pembangunan Kependudukan dan Keluarga Berencana Provinsi Jawa Tengah Tahun 2011.

BKKBN. (2017). Peraturan Kepala Badan Kependudukan dan Keluarga Berencana Nasional Nomor 24 tahun 2017 tentang Pelayanan Keluarga Berencana Pasca Persalinan dan Pasca Keguguran.Jakarta: BKKBN.

Fienalia, Rainy Alus. (2011). Faktor-faktor yang Berhubungan dengan Penggunaan Metode Kontrasepsi Jangka Panjang (MKJP) di Wilayah Kerja Puskesmas Pancoran Mas Kota Depok Tahun 2011. Depok: Universitas Indonesia.

Friedman, et al. (1994).A theory of the value of children. Demography

Hartoyo, Latifah, Mulyani. (2011). Studi Nilai Anak, Jumlah Anak yang diinginkan dan Keikutsertaan Orang Tua dalam Program KB. Jurnal Ilmiah Keluarga dan Konsultasi.Vol. 4, No. 1.Januari 2011.

Sumartini dan Indriani, D. (2014).Pengaruh Keinginan Pasangan Usia Subur (PUS) dalam Penggunaan Metode Kontrasepsi Jangka Panjang. Surabaya: Univerita Airlangga

Maryatun.(2007). Analisa Faktor-Faktor Pada Ibu yang Berpengaruh Terhadap Pemakaian Metode Kontrasepsi IUD di Kabupaten Sukoharjo. Semarang: UNDIP.

Paskaria, C. (2015). Faktor - Faktor Non Medis Yang Mempengaruhi Penggunaan MKJP Pada Wanita Pascasalin Di Indonesia. Journal of Medicine and Health vol I(2) Agustus 2015.

Proverawati, A., Islaely A.D., dan Aspuah, S. (2010). Panduan Memilih Kontrasepsi. Yogyakarta : Nuha Medika.

Purnandias, I.L Dan Dharminto,A.M. (2016). Hubungan Persepsi Efek Samping IUD, Dukungan Suami Dan Kepraktisan IUD Dengan Keikutsertaan Akseptor IUD Di 
Ratnasari, I Arifah \& T A I Kusumaningrum / Jurnal Kesehatan 14 (1) 2021, 68-78

Kelurahan Jatisari Kecamatan Mijen Kota Semarang Tahun 2016. Semarang: Universitas Diponegoro Semarang.

Puskesmas Purwosari. (2018). Laporan KB tahun 2018. Surakarta: Puskesmas Purwosari.

Putri, Chieng. (2017). Gambaran Dukungan Suami Terhadap Akseptor Kb IUD dan mplant Di Wilayah Kerja Puskesmas Gamping I Sleman Yogyakarta.Yogyakarta: Stikes Jenderal Achmad Yani

Singh, H. K, Singh, R. D., Singh, G. P., \& Kumar, A. (2010).Influence of sex composition on demand of child in uttar pradesh. Indian Journal of Preventive \& Social Medicine.

Sumartini dan Indriani, D. (2014).Pengaruh Keinginan Pasangan Usia Subur (PUS) dalam Penggunaan Metode Kontrasepsi Jangka Panjang. Surabaya: Univerita Airlangga

Triana, V., Wilopo, S.A, dan Sumarni.(2011). Hambatan Psikososial dan Niat Unmeet Need Kontrasepsi di Indonesia (Analisis Data SDKI 2007). Jurnal Kesehatan Masyarakat, 6(1):28-35.

Wulandari, Primei Putri. (2015). Hubungan dukungan suami mempunyai pengaruh yang terhadap pemilihan alat kontrasepsi pada PUS di Puskesmas Ngoresan Kota Surakarta. Surakarta: Universitas Sebelas Maret. 